Article

\title{
Different Effects of Nicotine and N-Stearoyl-ethanolamine on Episodic Memory and Brain Mitochondria of $\alpha 7$ Nicotinic Acetylcholine Receptor Knockout Mice
}

\author{
Olena Lykhmus, Olena Kalashnyk, Kateryna Uspenska, Tetyana Horid'ko®, Halyna Kosyakova, \\ Serhiy Komisarenko and Maryna Skok *D \\ Palladin Institute of Biochemistry, 01030 Kyiv, Ukraine; olenalykhmus@gmail.com (O.L.); \\ o.kalashnyk56@gmail.com (O.K.); kate.uspenska@gmail.com (K.U.); tangori@ukr.net (T.H.); \\ kosiakova@hotmail.com (H.K.); svk@biochem.kiev.ua (S.K.) \\ * Correspondence: skok@biochem.kiev.ua; Tel.: +380-44-234-33-54
}

Received: 16 December 2019; Accepted: 29 January 2020; Published: 3 February 2020

\begin{abstract}
Nicotinic acetylcholine receptors of $\alpha 7$ subtype ( $\alpha 7 \mathrm{nAChRs})$ are involved in regulating neuroinflammation and cognitive functions. Correspondingly, $\alpha 7-/-$ mice demonstrate pro-inflammatory phenotype and impaired episodic memory. In addition, $\mathrm{nAChRs}$ expressed in mitochondria regulate the release of pro-apoptotic factors like cytochrome c. Here we studied whether the cognitive deficiency of $\alpha 7-/-$ mice can be cured by oral consumption of either nicotine or N-stearoylethanolamine (NSE), a lipid possessing anti-inflammatory, cannabimimetic and membrane-stabilizing activity. Mice were examined in Novel Object Recognition behavioral test, their blood, brains and brain mitochondria were tested for the levels of interleukin-6, various nAChR subtypes and cytochrome c released by ELISA. The data presented demonstrate that both substances stimulated the raise of interleukin-6 in the blood and improved episodic memory of $\alpha 7-/-$ mice. However, NSE improved, while nicotine worsened the brain mitochondria sustainability to apoptogenic stimuli, as shown by either decreased or increased amounts of cytochrome c released. Both nicotine and NSE up-regulated $\alpha 4 \beta 2 \mathrm{nAChRs}$ in the brain; NSE up-regulated, while nicotine down-regulated $\alpha 9$-containing $n A C h R s$ in the brain mitochondria. It is concluded that the level of alternative $\mathrm{AChR}$ subtypes in the brain is critically important for memory and mitochondria sustainability in the absence of $\alpha 7 \mathrm{nAChRs}$.
\end{abstract}

Keywords: nicotinic acetylcholine receptor; nicotine; N-stearoylethanolamine; $\alpha 7$ knockout mice; memory; mitochondria

\section{Introduction}

Nicotinic acetylcholine receptors (nAChRs) are ligand-gated ion channels mediating fast synaptic transmission in muscles and autonomic ganglia, regulating the neurotransmitter release in the brain and involved in regulating the survival, proliferation and adhesion of many non-excitable cells [1-4]. The nAChRs of $\alpha 7$ subtype are involved in cholinergic anti-inflammatory pathway by attenuating the production of pro-inflammatory cytokines IL-1 $\beta$ and TNF $\alpha$ [5]. Correspondingly, the decrease of $\alpha 7 \mathrm{nAChRs}$ in the brain was observed upon neuroinflammation induced by regular injections of bacterial lipopolysaccharide (LPS) and, vice versa, decreasing the level of $\alpha 7 \mathrm{nAChRs}$ by immunization with $\alpha 7$ extracellular domain (1-208) resulted in neuroinflammation [6]. Neuroinflammation is closely related to cognition: the memory decline observed upon neurodegenerative disorders like Alzheimer's disease is accompanied or even preceded by neuroinflammation [7-9]. 
In addition to the cell plasma membrane, several nAChR subtypes, including $\alpha 7$-containing subtype, were found in the outer membrane of mitochondria, where they regulate the release of pro-apoptotic factors like cytochrome $\mathrm{c}$ (cyt c) caused by the increase of intracellular $\mathrm{Ca}^{2+}$ or reactive oxygen species [10]. The decrease of mitochondrial nAChRs observed upon inflammation was shown to be accompanied by increased cyt $c$ release under the effect of $\mathrm{Ca}^{2+}$ or $\mathrm{H}_{2} \mathrm{O}_{2}$ [11].

Mutant mice lacking $\alpha 7 \mathrm{nAChRs} \mathrm{(} \alpha 7-/-)$ were shown to possess pro-inflammatory phenotype with increased level of pro-inflammatory cytokines in the blood, spleen and brain [12-14]. Initial studies did not demonstrate any cognitive differences between the wild-type (WT) and $\alpha 7-/-$ mice [15]. Later it was found that $\alpha 7-/$ - mice were different in the anxiety-related behavior [16], attention $[17,18]$ and visual activity [19]. In our hands, the $\alpha 7-/-$ mice demonstrated higher locomotor and explorative activity but impaired episodic memory measured in the Novel Object Recognition (NOR) test [20]. Their mitochondria were more sensitive to $\mathrm{Ca}^{2+}$ compared to mitochondria of the WT mice. However, the difference was not dramatic due to compensatory up-regulation of mitochondrial $\alpha 4$ - and $\alpha 9$-containing nAChRs [21].

Previously we reported that episodic memory decline and mitochondrial impairment in LPS-treated mice can be prevented by treatment with N-stearoylethanolamine (NSE), a natural component of cellular membranes possessing cannabimimetic, anti-inflammatory and membranestabilizing activity [22]. Here we asked if NSE can improve memory and stabilize mitochondria in the absence of $\alpha 7 \mathrm{nAChRs}$ in $\alpha 7-/$ - mice. The effect of NSE was compared with that of nicotine known to activate $\alpha 4 \beta 2 \mathrm{nAChRs}$ critically important for memory and cognition [3,23].

\section{Materials and Methods}

\subsection{Reagents}

All reagents were of chemical grade and purchased from Sigma-Aldrich (Saint Louis, MO, USA), unless specially indicated. Antibodies against $\alpha 3(181-192), \alpha 4(181-192), \alpha 5(180-191), \alpha 7(179-190)$, $\alpha 9(11-23)$ or $\alpha 7(1-208) n A C h R$ fragments and rabbit cyt $c$-specific antibodies were generated using methods previously developed in our lab [24-28]. The antibodies were biotinylated according to standard procedures [29]. Mouse IL-6 ELISA Ready-SET (Ref \# 88-7064-88) was purchased from ALT Ukraine Ltd. (Kyiv, Ukraine, official representative of Thermo Fisher Scientific in Ukraine). NSE was synthesized in the Department of Lipid Biochemistry at Palladin Institute of Biochemistry as described previously $[22,30]$.

\subsection{Animals}

We used the C57Bl/6 (WT) and $\alpha 7-/-$ male mice 3-5 months of age. The colony of $\alpha 7-/-$ mice was developed in Kyiv from a nucleus kindly presented by Dr. Uwe Maskos from Institut Pasteur, Paris. Mice were kept in the animal facility of Palladin Institute of Biochemistry NAS of Ukraine, were housed in quiet, temperature-controlled rooms and provided with water and food pellets ad libitum. Before removing the brains, mice were sacrificed by cervical dislocation. All procedures complied with the ARRIVE guidelines, were carried out in accordance with the Directive 2010/63/EU for animal experiments and were approved by the Animal Care and Use Committee of Palladin Institute of Biochemistry.

\subsection{Experimental Schedule and the Brain Preparations}

The $\alpha 7-/-$ mice were randomly divided into three groups, five animals in each. One group was fed with NSE per os, $50 \mathrm{mg} \mathrm{kg}^{-1}, 50 \mu \mathrm{L}$ per mouse during 7 days. Another group obtained nicotine with the drinking water $(200 \mu \mathrm{L} / \mathrm{L})$ during three weeks. The blood was taken from the tail vein on day 0 (all groups), day 14 (one week after cessation of NSE treatment) or day 21 (nicotine). The mice were examined in behavioral test on days 0,7 and 14 or 21 and sacrificed. 
The WT mice were divided into two groups, three animals in each. Both groups were injected intraperitoneally with lipopolysaccharide (LPS, E. coli strain 055:B5, $1.5 \mathrm{mg} / \mathrm{kg}$ ) in PBS. One group of mice obtained four subcutaneous injections of recombinant IL-6 (750 pg in $50 \mu \mathrm{L})$ once per day starting from day 4 after LPS injection. The mice were examined in behavioral test on days 0 (before LPS injection), 7 and 14 and sacrificed.

The mouse brains were homogenized in a glass homogenizer in sucrose-containing buffer $(10 \mathrm{mM}$ HEPES, $1 \mathrm{mM}$ EGTA, $200 \mathrm{mM}$ sucrose) and centrifuged $\left(1500 \times g, 10 \mathrm{~min}, 4{ }^{\circ} \mathrm{C}\right)$. The pellet was considered as a non-mitochondria fraction, while the supernatant was additionally centrifuged $(2 \times$ $10 \mathrm{~min}, 8500 \times \mathrm{g}$ at $4^{\circ} \mathrm{C}$ ) and the pellet (mitochondria) was resuspended in mitochondria incubation medium and used for functional cyt $c$ release assay (see Section 2.5). The pellets of both mitochondria (collected after cyt c release) and non-mitochondria fractions were used to prepare the detergent lysates, as described previously [6]. The purity of mitochondrial and non-mitochondrial brain fractions obtained was evaluated by ELISA using the antibodies against different cellular compartments, as described previously [31].

\subsection{ELISAS}

The level of various $\mathrm{nAChR}$ subunits within the brain or mitochondria preparations was studied as described previously [6]. Briefly, the immunoplates (Nunc MaxiSorp, purchased from ALT Ukraine Ltd. (Kyiv, Ukraine, official representative of Thermo Fisher Scientific in Ukraine). were coated with rabbit $\alpha 7(1-208)$-specific antibody $(20 \mu \mathrm{g} / \mathrm{mL})$, blocked with $1 \% \mathrm{BSA}$, and the detergent lysates of brain tissue or mitochondria were applied into the wells $(1 \mu \mathrm{g}$ of protein per $0.05 \mathrm{~mL}$ per well) for $2 \mathrm{~h}$ at $37^{\circ} \mathrm{C}$. The plates were washed with water and the second biotinylated $\alpha 3(181-192)-, \alpha 4(181-192)-$, $\alpha 7(179-190)-, \alpha 9$ (11-23)-, $\beta 2$ (190-200)- or $\beta 4(190-200)$-specific antibody was applied for additional $2 \mathrm{~h}$ being revealed with neutravidin-peroxidase conjugate and $o$-phenylendiamine-containing substrate solution. The level of IL-6 in the blood sera was measured using IL-6-specific ELISA kit and procedure recommended by manufacturer. The optical density of ELISA plates was read using Stat-Fax 2000 ELISA Reader (Awareness Technologies, Westport, CT, USA).

\subsection{Cyt c Release Assay}

The purified brain mitochondria $(120 \mu \mathrm{g}$ of protein per $\mathrm{ml})$ were incubated with either $0.9 \mu \mathrm{M}$ $\mathrm{CaCl}_{2}$ or $0.5 \mathrm{mM} \mathrm{H}_{2} \mathrm{O}_{2}$ for $5 \mathrm{~min}$ at room temperature and were immediately pelleted by centrifugation $(10 \mathrm{~min}, 7000 \times \mathrm{g})$ at $4^{\circ} \mathrm{C}$. The incubation medium contained $10 \mathrm{mM} \mathrm{HEPES}, 125 \mathrm{mM} \mathrm{KCl}, 25 \mathrm{mM} \mathrm{NaCl}$, $5 \mathrm{mM}$ sodium succinate and $0.1 \mathrm{mM} \mathrm{Pi}(\mathrm{K}), \mathrm{pH}$ 7.4. The mitochondria supernatants were collected and tested for the presence of cyt $c$ by sandwich assay as described previously $[10,28]$.

\subsection{Behavioral Test}

Mice were tested in the "Novel Object Recognition" (NOR) behavioral test [6,32] prior and each week post-treatments. Briefly, the animals were individually placed in a rectangular novel open field containing two identical objects with distinctive features (shape and texture). The animals were subjected to a 10-min session of exploration of the objects followed by $10 \mathrm{~min}$ in a waiting cage. During the second 10-min session, one of the objects was replaced by a novel one and we scored the time spent in contact with each object. It is widely acknowledged that rodents spontaneously explore novel objects by touching the objects with their nose and prefer novel objects to familiar ones that reflect their episodic memory [33,34]. Therefore, the time spent in contact with each object reflects the time of exploration for the object. The results of NOR test are presented as Discrimination Index (DI) calculated as the difference in the number of "novel" and "famous" object explorations divided by the total number of explorations of two identical objects. 


\subsection{Statistical Analysis}

ELISA experiments have been performed in triplicates and mean values for individual mice were used for statistical analysis using one-way ANOVA test. Behavioral tests were performed three times (days 0,7 and 14 or 21) for each mouse and counts of individual mice were taken for statistical analysis. The data are presented as Mean $\pm \mathrm{SD} ;{ }^{*} p<0.05 ;{ }^{* *} p<0.005 ;{ }^{* * *} p<0.0005$.

\section{Results}

The $\alpha 7-/-$ mice demonstrated significantly worse episodic memory compared to the WT mice; this difference was maintained during all experimental period. Consuming nicotine with the drinking water increased the discrimination index of the new $v$ s familiar objects recognition already after seven days. After three weeks of nicotine consumption the memory of $\alpha 7-/$ - mice was similar, or even better, than that of the WT mice (Figure 1a). NSE, given during a week, improved memory of the $\alpha 7-/-$ mice and the effect was further developed a week afterwards (Figure 1b).

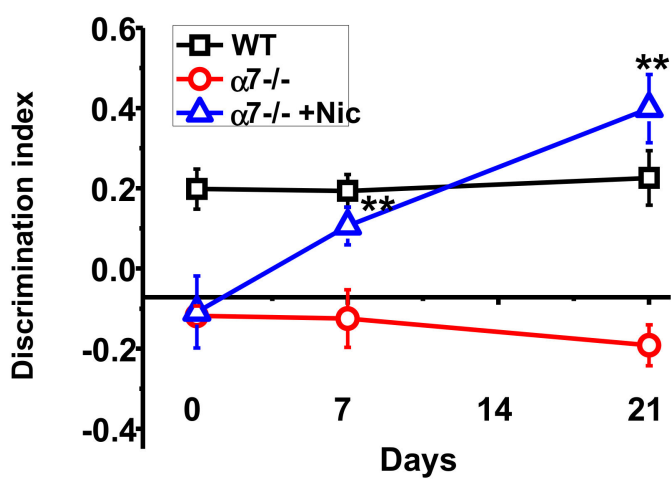

(a)

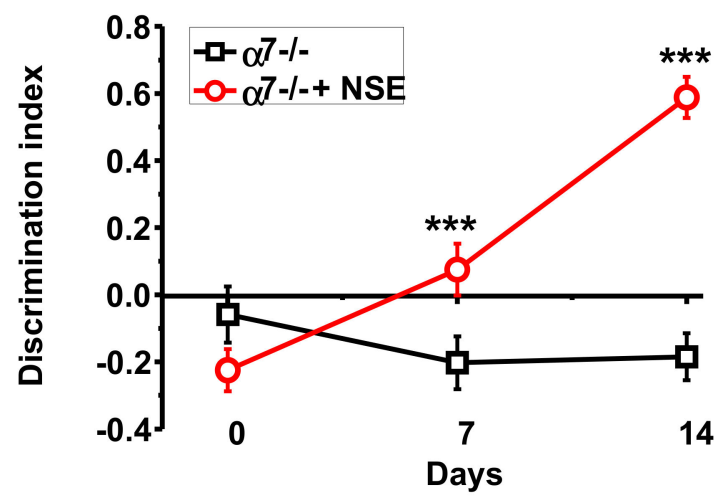

(b)

Figure 1. Memory (discrimination index studied in NOR test) of $\alpha 7-/-$ mice under the effect of either nicotine (a) or NSE (b). Each point on the curve corresponds to $\mathrm{M} \pm \mathrm{SD}, \mathrm{n}-5$. ${ }^{* *} p<0.005$; ${ }^{* * *} p<0.0005$ compared to Day 0 (non-treated mice). WT-wild-type C57Bl mice.

The brains of mice were fractionated into mitochondria and non-mitochondria fractions. According to ELISA with the cell compartment-specific antibodies, the mitochondria fraction was positive for mitochondria-specific voltage-dependent anion channels (VDAC) and negative for nuclear-specific lamin B1 and endoplasmic reticulum-specific IRE- $1 \alpha$, while the "non-mitochondria" fraction contained lamin $1 \mathrm{~B}$ and IRE- $1 \alpha$, but not VDAC [31].

The non-mitochondria brain fraction of $\alpha 7-/-$ mice contained elevated amounts of $\alpha 4, \alpha 9, \alpha 10$ and $\beta 4 \mathrm{nAChR}$ subunits compared to corresponding fraction of the WT mice (Figure 2a). Consuming nicotine did not influence $\alpha 9$ and $\alpha 10$ subunits but increased $\alpha 4, \beta 2$ and, less, $\beta 4$ subunits. Consuming NSE also increased $\alpha 4, \beta 2$ and, in addition, $\alpha 3 \mathrm{nAChR}$ subunits (Figure $2 b$ ).

Interleukin-6 (IL-6) is usually regarded as one of pro-inflammatory cytokines. However, in addition, it has been regarded as a neurotrophic factor [35]. Previously we reported that subcutaneous injections of recombinant IL- 6 up-regulated $\alpha 3 \beta 4$ and $\alpha 4 \beta 2$ nAChRs in the brain of $\alpha 7-/-$ mice and improved their episodic memory [20]. Here we asked if IL-6 can prevent pathogenic effect of inflammation in wild-type C57Bl/6 mice. 


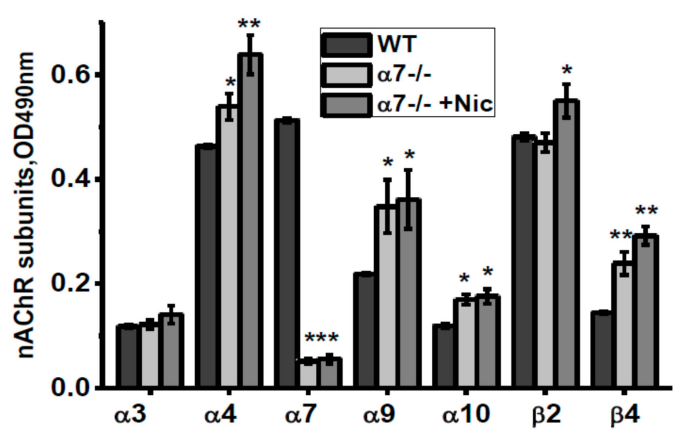

(a)

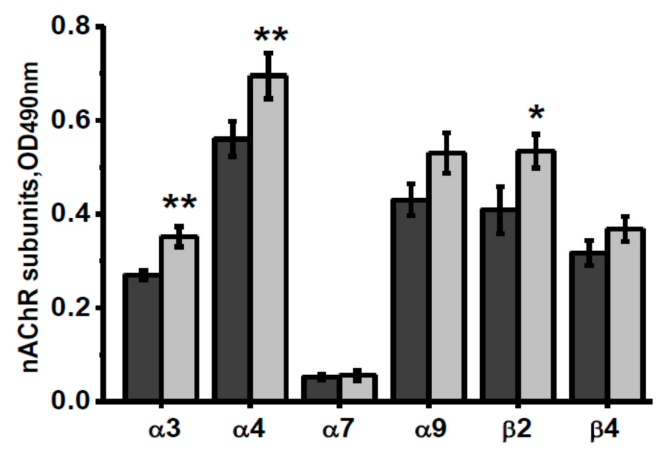

(b)

Figure 2. nAChR subunits composition in the brain (w/o mitochondria) fractions of $\alpha 7-/-$ mice under the effect of either nicotine (a) or NSE (b). Each column corresponds to M \pm SD, n-5. ${ }^{*} p<0.05$; ** $p<0.005$ compared to non-treated WT mice (a) or $\alpha 7-/-$ mice (b).

As shown in Figure 3a, episodic memory of mice injected with LPS was gradually decreased during two weeks and this was not the case if mice were injected with recombinant IL- 6 the first four days after LPS injection. Sandwich ELISA using the antibodies against different nAChR subunits demonstrated that IL-6 injections up-regulated $\alpha 3, \alpha 4, \alpha 7, \alpha 9$ and $\beta 2$ nAChR subunits, some of them being down-regulated by LPS (Figure 3b).

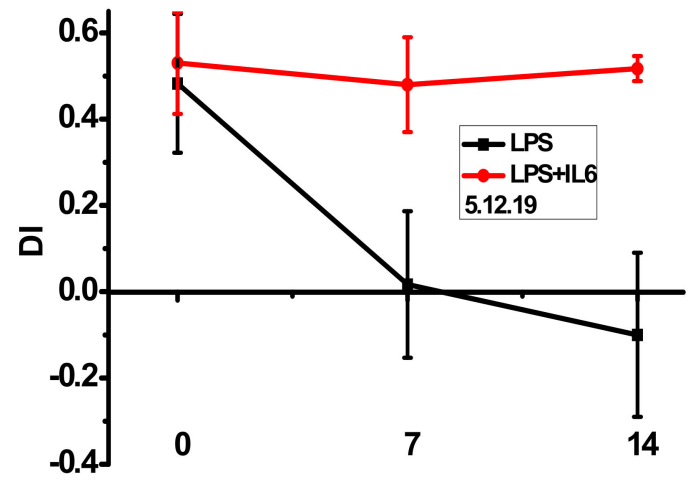

(a)

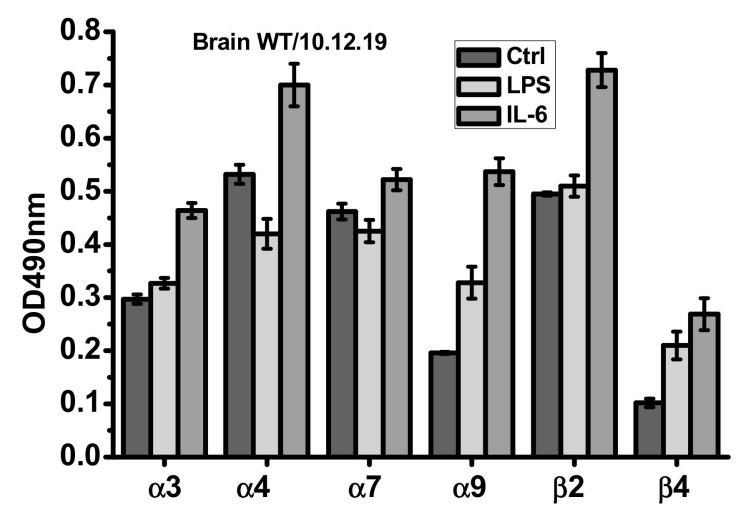

(b)

Figure 3. Episodic memory (discrimination index studied in NOR test) (a) and nAChR subunit composition in the brain (w/o mitochondria, (b) of the wild-type mice injected with either LPS alone or LPS and IL-6. Ctrl-non-injected mice. ${ }^{* *} p<0.005 ;{ }^{* * *} p<0.0005$ compared to LPS-treated mice, $n=3$.

To check if nicotine or NSE influence the IL-6 level in $\alpha 7-/-$ mice we measured this cytokine in the blood of mice under experiment. As shown in Figure 4, both nicotine and NSE significantly increased the amount of IL-6 in the blood of $\alpha 7-/-$ mice at the time point when memory improvement was observed. Therefore, the memory-improving effects of both NSE and nicotine could be related to increased IL-6 levels. 


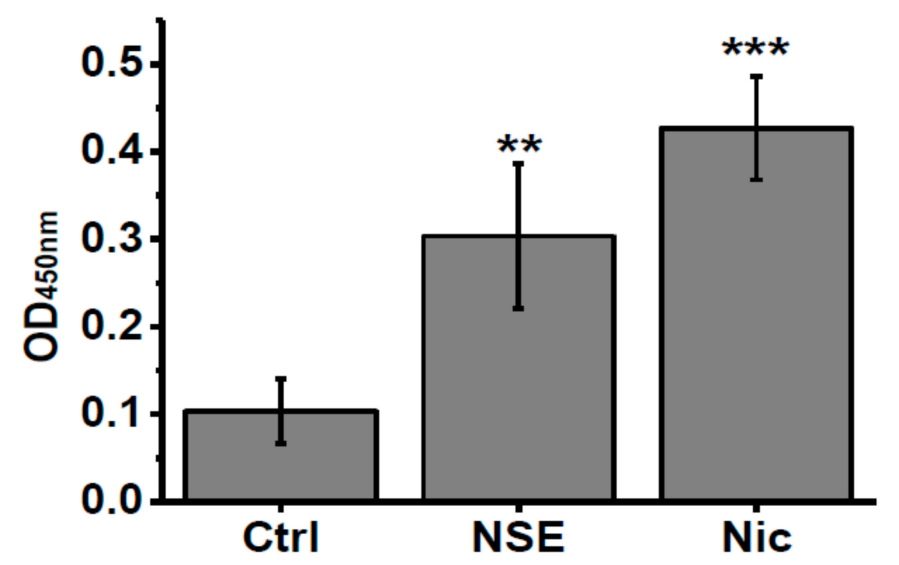

Figure 4. Level of IL-6 in the blood sera of $\alpha 7-/-$ mice under the effect of either nicotine or NSE. Each column corresponds to $\mathrm{M} \pm \mathrm{SD}, \mathrm{n}-5$. ${ }^{* *} p<0.005$; ${ }^{* * *} p<0.0005$ compared to non-treated $\alpha 7-/-$ mice (Ctrl).

To check how nicotine or NSE consumption affected the brain mitochondria sustainability to apoptogenic influence, we measured the amounts of cyt c released from isolated mitochondria under the effect of either $\mathrm{Ca}^{2+}$ or $\mathrm{H}_{2} \mathrm{O}_{2}$. As shown in Figure 5, nicotine consumption increased, while NSE consumption attenuated cyt c release from mitochondria of $\alpha 7-/-$ mice stimulated by these apoptogenic agents.

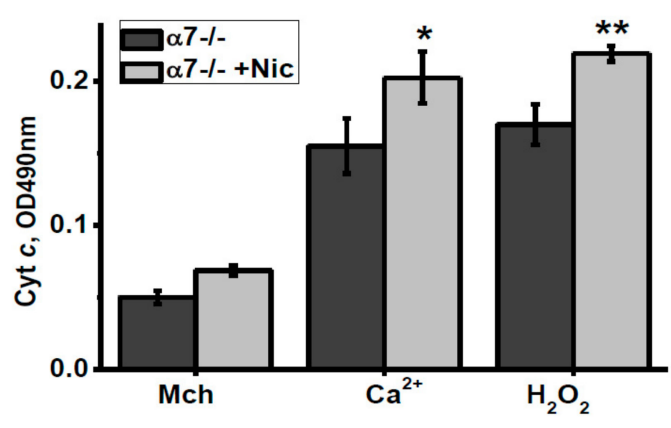

(a)

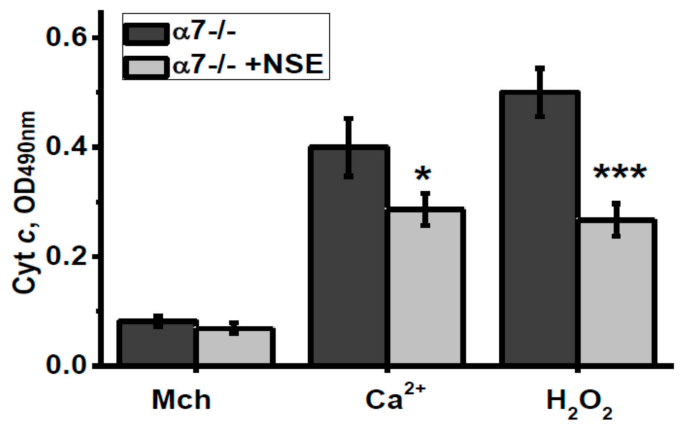

(b)

Figure 5. Level of cytochrome c (Cyt c) released from the brain mitochondria of $\alpha 7-/-$ mice treated by either nicotine (a) or NSE (b) under the effect of $0.9 \mu \mathrm{M} \mathrm{Ca}^{2+}$ or $0.5 \mathrm{mM} \mathrm{H}_{2} \mathrm{O}_{2}$. Each column corresponds to $\mathrm{M} \pm \mathrm{SD}, \mathrm{n}-5$. ${ }^{*} p<0.05 ;{ }^{* *} p<0.005 ;{ }^{* * *} p<0.0005$ compared to non-treated $\alpha 7-/-$ mice. Mch—cyt c released from non-treated mitochondria.

According to ELISA data, mitochondria of $\alpha 7-/-$ mice contained more $\alpha 4, \alpha 9, \beta 2$ and $\beta 4$ nAChR subunits compared to mitochondria of the WT mice (Figure 6a). Nicotine consumption decreased $\alpha 9$ and $\beta 4 \mathrm{nAChR}$ subunits, while NSE consumption increased $\alpha 3$ and $\alpha 9$ subunits compared to mitochondria of non-treated $\alpha 7-/$ - mice (Figure $6 \mathrm{a}, \mathrm{b}$ ). 


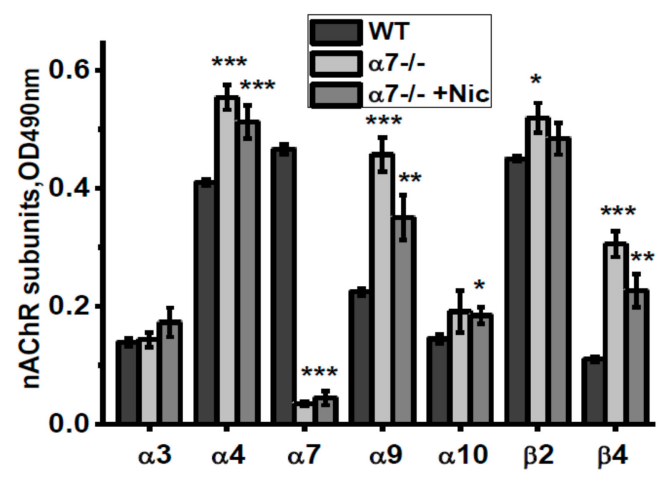

(a)

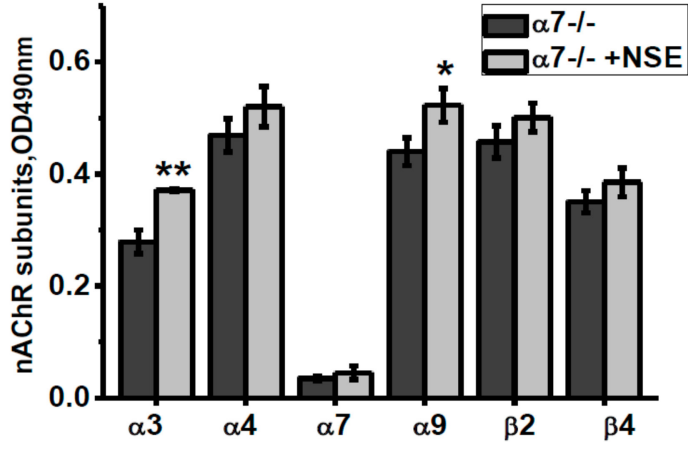

(b)

Figure 6. nAChR subunits composition in the brain mitochondria of $\alpha 7-/-$ mice under the effect of either nicotine (a) or NSE (b). Each column corresponds to $\mathrm{M} \pm \mathrm{SD}, \mathrm{n}-5 .{ }^{*} p<0.05 ;{ }^{* *} p<0.005$; ${ }^{* * *} p<0.0005$ compared to non-treated WT mice (a) or $\alpha 7-/-$ mice (b).

\section{Discussion}

Our previous studies clearly showed that neuroinflammation is accompanied by the down-regulation of $\alpha 7 \mathrm{nAChRs}$ in the brain and, vice versa, decreasing the level of $\alpha 7 \mathrm{nAChRs}$ by corresponding antibodies results in neuroinflammation and memory deficiency [6]. In addition, we were the first to show the presence of nAChRs in the outer membrane of mitochondria and their involvement in the early stages of mitochondria-driven apoptosis [10]. Correspondingly, neuroinflammation negatively affected mitochondria sustainability [11]. These studies pushed us to search the approaches to overcome the pathological effects of neuroinflammation and $\alpha 7 \mathrm{nAChR}$ deficiency. In particular, it was shown that neuroinflammation can be prevented or even cured by activating $\alpha 7 \mathrm{nAChRs}$ with orthosteric agonist [36] or by up-regulating alternative $\mathrm{nAChR}$ subtypes with the growth factors produced by mesenchymal stem cells [37]. One of our previous papers described the efficiency of NSE to prevent neuroinflammation in the wild-type mice either treated with LPS of immunized with $\alpha 7 \mathrm{nAChR}$ extracellular domain 1-208 [22]. The present manuscript continues this set of studies by employing the "end-point" model of $\alpha 7 \mathrm{nAChR}$ deficiency — knockout mice completely lacking this nAChR subtype-to show that although up-regulation/activation of alternative nAChR subtypes is an efficient approach to support/improve cognitive functions, the most obvious way, like nicotine consumption, is not good because it negatively affects the brain mitochondria.

The data presented here demonstrate that episodic memory of $\alpha 7-/-$ mice can be improved by either nicotine or NSE. However, NSE improved, while nicotine worsened the brain mitochondria sustainability to apoptogenic stimuli, as shown by either decreased or increased amounts of cyt c released from isolated mitochondria. These phenomena seem to correlate with the nAChR content/composition: both nicotine and NSE up-regulated $\alpha 4 \beta 2 \mathrm{nAChRs}$ in the brain; NSE up-regulated, while nicotine down-regulated $\alpha 9$-containing nAChRs in the brain mitochondria of $\alpha 7-/-$ mice.

Both the mitochondria and non-mitochondria fractions of $\alpha 7-/-$ mice contained elevated amounts of other nAChR subunits compared to corresponding fractions of the WT mice: $\alpha 4, \alpha 9, \beta 2$ and $\beta 4$ in mitochondria and $\alpha 4, \alpha 9, \alpha 10$ and $\beta 4$ subunits in non-mitochondria. This data is in accord with our previous results [21] and is consistent with the idea that the absence of $\alpha 7$-containing nAChRs is compensated by up-regulation of alternative $\mathrm{nAChR}$ subtypes. According to established $\mathrm{nAChR}$ subunit combinations, these could be $\alpha 4 \beta 2 / \alpha 4 \beta 4$ and $\alpha 9 \alpha 10$ nAChRs. In addition, we previously showed the presence of $\alpha 9 \beta 4$ combination in mitochondria of $\alpha 7-/$ - mice and in rats subjected to partial hepatectomy by sandwich ELISA using a pair of $\alpha 9$ - and $\beta 4$-specific antibodies [21] that is also supported by the present data. The absence of $\alpha 7$-containing nAChRs did not significantly influence cyt $\mathrm{c}$ release from their mitochondria under the effect of either $\mathrm{Ca}^{2+}$ or $\mathrm{H}_{2} \mathrm{O}_{2}$ [21]; therefore, the $\mathrm{nAChR}$ subtypes expressed in compensation were sufficient to support mitochondria protection against apoptogenic stimuli. In contrast, the nAChRs up-regulated in non-mitochondria fraction of 
the brain ( $\alpha 4 \beta 4$ and $\alpha 9 \alpha 10)$, potentially including plasma membrane $\mathrm{nAChRs}$, were not sufficient to control inflammation [12] or to fully support episodic memory in $\alpha 7-/-$ mice.

Both nicotine and NSE treatment up-regulated $\alpha 4 \beta 2 \mathrm{nAChRs}$ in non-mitochondria brain fraction and improved memory. This is consistent with the principal role of $\alpha 4 \beta 2 \mathrm{nAChRs}$ in learning and memory [23]. Interestingly, such improvement was accompanied by increased peripheral IL-6 production. Previously we found that recombinant IL- 6 up-regulated $\alpha 4 \beta 2 \mathrm{nAChRs}$ in the brain of $\alpha 7-/-$ mice and improved their memory [20]. Here we provide evidence that injections of recombinant IL-6 prevented episodic memory decline under the effect of LPS and up-regulated several nAChR subtypes in the brain of the wild-type mice. Therefore, it seems realistic to suggest that the effects of both nicotine and NSE in the brains of $\alpha 7-/$ - mice are, at least partly, mediated by IL- 6 . In addition to its pro-inflammatory function, IL-6 is considered as a neurotrophic factor [35] and its effect appears to be sufficient to compensate the $\alpha 7 \mathrm{nAChR}$ deficiency, at least, related to episodic memory.

Interestingly, the effects of NSE or nicotine on the brain mitochondria were opposite: NSE increased mitochondria sustainability to apoptogenic influence and up-regulated $\alpha 9$-containing nAChRs, while nicotine decreased sustainability and down-regulated $\alpha 9$-containing nAChRs. Previously we reported that NSE stabilized mitochondria of LPS-treated WT mice and restored their $\alpha 7 \mathrm{nAChRs}$ decreased by inflammation [22] that is consistent with the present data. We also found that nicotine consumption by the WT mice facilitated the $\alpha 4 \beta 2 \mathrm{nAChR}$ trafficking to the liver mitochondria, did not influence other nAChR subtypes and did not affect the mitochondria sensitivity to $\mathrm{Ca}^{2+}$ [31]. Here we show that nicotine decreased the level of $\alpha 9$ - and $\beta 4$-containing nAChRs in the brain mitochondria of $\alpha 7-/-$ mice (up-regulated to compensate the absence of $\alpha 7 \mathrm{nAChRs}$ ) that worsened the mitochondria sustainability. This data indicates that the effect of nicotine on mitochondria is different in either the presence (WT) or absence of $\alpha 7 \mathrm{nAChRs}(\alpha 7-/-)$. Possibly, this could be explained by different consequences of nicotine interaction with either $\alpha 7$ - or $\alpha 9$-containing nAChRs. Nicotine is an agonist for $\alpha 7 \mathrm{nAChRs}$ but is antagonistic towards $\alpha 9 \mathrm{nAChRs} \mathrm{[38].} \mathrm{In} \mathrm{addition,} \mathrm{different} \mathrm{types} \mathrm{of} \mathrm{intracellular} \mathrm{signaling} \mathrm{were}$ suggested for these two nAChR subtypes $[39,40]$. In one of our previous papers we showed the presence of $\alpha 9$-containing nAChRs in the brain of WT C57B1/6 mice and their up-regulation in $\alpha 7-/-$ mice [41]. Those data were in contradiction to previously established absence of $\alpha 9$ expression in the brain [42] and provoked certain criticism [43]. The results presented here support our previous findings and demonstrate that, at least in the brain mitochondria, the $\alpha 9$-containing nAChRs can be responsible for the sustainability to apoptogenic stimuli and for unusual effect of nicotine in $\alpha 7-/-$ mice.

Taken together, the data presented here confirm the previously established important role of $\alpha 7$ nAChRs for cognitive processes like episodic memory $[44,45]$ and suggest the approaches to improve it in the absence of this nAChR subtype. It is quite clear that memory impairment caused by $\alpha 7$ $\mathrm{nAChR}$ deficiency can be compensated by up-regulation of $\alpha 4 \beta 2 \mathrm{nAChRs}$, which can be achieved by interventions stimulating neurotrophic factors (eg. IL-6) production. However, nicotine, which is a classical nAChR ligand stimulating $\alpha 4 \beta 2 \mathrm{nAChRs}$, cannot be recommended for this purpose because it negatively affects the brain mitochondria. In addition to its previously established negative effect on mitochondria respiratory chain, that is receptor-independent [46], it down-regulates $\alpha 9 \beta 4 \mathrm{nAChRs,}$ which compensate the $\alpha 7 \mathrm{nAChR}$ deficiency, and makes mitochondria more sensitive to apoptogenic influence. In contrast, NSE positively affects both memory and mitochondria and, therefore, can be a drug of choice to restore the cognitive functions impaired by $\alpha 7 \mathrm{nAChR}$ deficiency. Although complete absence of $\alpha 7 \mathrm{nAChRs}$ is not described in the wild-type animals or humans, its partial deficiency may be critical, for example, upon inflammation.

NSE is a natural component of mammalian cell membranes, along with N-palmitoyl-ethanolamine, $\mathrm{N}$-oleylethanolamine and N-linoleylethanolamine, which are important and physiologically relevant mediators of cell protection against various pathological conditions [47]. In addition to direct incorporation into the cell membranes, $\mathrm{N}$-acylethanolamines were shown to interact with cannabinoid, vanyloid and nuclear PPAR receptors [48-50]. NSE was shown to possess cannabimimetic activity; however, its binding sites found in mouse brain are different from cannabinoid receptors [51]. 
Previous experiments demonstrated neuroprotective effect of NSE in the model of chronic morphine dependence $[52,53]$ and its anti-acetylcholine esterase and pro-cognitive activity in the model of cholinergic deficiency caused by scopolamine [54]. We also showed that NSE restored memory and $\alpha 7 \mathrm{nAChR}$ content and stabilized mitochondria in the brains of WT mice either injected with LPS or immunized with the $\alpha 7$ extracellular domain (1-208) [22]. The present study confirms this data and shows the efficiency of NSE even in complete absence of $\alpha 7 \mathrm{nAChRs}$. Production of endogenous $\mathrm{N}$-acylethanolamines was shown to be dependent on $\alpha 7 \mathrm{nAChR}$ activation [55]; therefore, consumption of exogenous NSE by $\alpha 7-/$ - mice can compensate the deficiency of endogenous compound. Correspondingly, one may suggest that $\mathrm{N}$-acylethanolamines are mediators of at least a part of $\alpha 7$ nAChR physiological effects.

\section{Conclusions}

(1) In the absence of $\alpha 7 \mathrm{nAChRs}$, the levels of $\alpha 4 \beta 2 \mathrm{nAChRs}$ in the brain and of $\alpha 9 \mathrm{nAChRs}$ in the brain mitochondria are critically important for memory and mitochondria sustainability, respectively.

(2) Both nicotine and NSE stimulate IL-6 production, which favor up-regulation of alternative nAChR subtypes in $\alpha 7-/$ - and LPS-injected wild-type mice.

(3) Nicotine improves memory of $\alpha 7-/-$ mice but negatively affects the brain mitochondria.

(4) NSE positively affects both memory and mitochondria and, therefore, can be a drug of choice to restore the cognitive functions impaired by $\alpha 7 \mathrm{nAChR}$ deficiency.

(5) Taking into account the established role of $\alpha 7 \mathrm{nAChRs}$ in neuroinflammation, the results of our study demonstrate a therapeutic potential of NSE in treating neuroinflammation-dependent neurodegenerative disorders, like Alzheimer disease.

Author Contributions: Conceptualization, H.K. and M.S.; methodology, O.L., O.K. and T.H.; investigation, O.L., O.K., K.U., T.H.; resources, T.H. and H.K.; data curation, O.L.; writing-original draft preparation, M.S.; writing-review and editing, M.S., S.K., O.L., H.K. All authors have read and agreed to the published version of the manuscript.

Funding: This research received no external funding.

Conflicts of Interest: The authors declare no conflict of interest.

\section{References}

1. Kalamida, D.; Poulas, K.; Avramopoulou, V.; Fostieri, E.; Lagoumintzis, G.; Lazaridis, K.; Sideri, A.; Zouridakis, M.; Tzartos, S.J. Muscle and neuronal nicotinic acetylcholine receptors. Structure, function and pathogenicity. FEBS J. 2007, 274, 3799-3845. [CrossRef] [PubMed]

2. Skok, V.I. Nicotinic acetylcholine receptors in autonomic ganglia. Auton. Neurosci. 2002, 97, 1-11. [CrossRef]

3. Gotti, C.; Clementi, F.; Fornari, A.; Gaimarri, A.; Guiducci, S.; Manfredi, I.; Moretti, M.; Pedrazzi, P.; Pucci, L.; Zoli, M. Structural and functional diversity of native brain neuronal nicotinic receptors. Biochem. Pharmacol. 2009, 78, 703-711. [CrossRef] [PubMed]

4. Kawashima, K.; Fujii, T. Basic and clinical aspects of non-neuronalacetylcholine: Overview of non-neuronal cholinergic systems and their biological significance. J. Pharmacol. Sci. 2008, 106, 167-173. [CrossRef] [PubMed]

5. De Jonge, W.J.; Ulloa, L. The alpha7 nicotinic acetylcholine receptor as a pharmacological target for inflammation. Br. J. Pharmacol. 2007, 151, 915-929. [CrossRef] [PubMed]

6. Lykhmus, O.; Voytenko, L.; Koval, L.; Mykhalskiy, S.; Kholin, V.; Peschana, K.; Zouridakis, M.; Tzartos, S.; Komisarenko, S.; Skok, M. $\alpha 7$ Nicotinic acetylcholine receptor-specific antibody induces inflammation and amyloid $\beta_{42}$ accumulation in the mouse brain to impair memory. PLoS ONE 2015, 10, e0122706. [CrossRef] [PubMed]

7. Chung, Y.C.; Ko, H.W.; Bok, E.; Park, E.S.; Huh, S.H.; Nam, J.H.; Jin, B.K. The role of neuroinflammation on the pathogenesis of Parkinson's disease. BMB Rep. 2010, 43, 225-232. [CrossRef]

8. Heppner, F.L.; Ransohoff, R.M.; Becher, B. Immune attack: The role of inflammation in Alzheimer disease. Nat. Rev. Neurosci. 2015, 16, 358-372. [CrossRef] 
9. Heneka, M.T.; Carson, M.J.; El Khoury, J.; Landreth, G.E.; Brosseron, F.; Feinstein, D.L.; Jacobs, A.H.; Wyss-Coray, T.; Vitorica, J.; Ransohoff, R.M.; et al. Neuroinflammation in Alzheimer's disease. Lancet Neurol. 2015, 14, 388-405. [CrossRef]

10. Gergalova, G.L.; Lykhmus, O.Y.; Kalashnyk, O.M.; Koval, L.M.; Chernyshov, V.O.; Kryukova, E.A.; Tsetlin, V.I.; Komisarenko, S.V.; Skok, M.V. Mitochondria express $\alpha 7$ nicotinic acetylcholine receptors to regulate $\mathrm{Ca}^{2+}$ accumulation and cytochrome $c$ release: Study on isolated mitochondria. PLOS ONE 2012, 7, e31361. [CrossRef]

11. Lykhmus, O.; Gergalova, G.; Zouridakis, M.; Tzartos, S.; Komisarenko, S.; Skok, M. Inflammation decreases the level of alpha7 nicotinic acetylcholine receptors in the brain mitochondria and makes them more susceptible to apoptosis induction. Int. Immunopharmacol. 2015, 29, 148-151. [CrossRef] [PubMed]

12. Truong, L.D.; Trostel, J.; Garcia, G.E. Absence of nicotinic acetylcholine receptor $\alpha 7$ subunit amplifies inflammation and accelerates onset of fibrosis: An inflammatory kidney model. FASEB J. 2015, 29, 3558-3570. [CrossRef] [PubMed]

13. Zhang, J.C.; Yao, W.; Ren, Q.; Yang, C.; Dong, C.; Ma, M.; Wu, J.; Hashimoto, K. Depression-like phenotype by deletion of $\alpha 7$ nicotinic acetylcholine receptor: Role of BDNF-TrkB in nucleus accumbens. Sci. Rep. 2016, 6, 36705. [CrossRef] [PubMed]

14. Kawashima, K.; Fujii, T.; Moriwaki, Y.; Misawa, H.; Horiguchi, K. Non-neuronal cholinergic system in regulation of immune function with a focus on $\alpha 7 \mathrm{nAChRs.} \mathrm{Int.} \mathrm{Immunopharmacol.} \mathrm{2015,} \mathrm{29,} \mathrm{127-134.}$ [CrossRef]

15. Orr-Urtreger, A.; Göldner, F.M.; Saeki, M.; Lorenzo, I.; Goldberg, L.; De Biasi, M.; Dani, J.A.; Patrick, J.W.; Beaudet, A.L. Mice deficient in the alpha7 neuronal nicotinic acetylcholine receptor lack alpha-bungarotoxin binding sites and hippocampal fast nicotinic currents. J. Neurosci. 1997, 17, 9165-9171. [CrossRef]

16. Paylor, R.; Nguyen, M.; Crawley, J.N.; Patrick, J.; Beaudet, A.; Orr-Urtreger, A. Alpha7 nicotinic receptor subunits are not necessary for hippocampal-dependent learning or sensorimotor gating: A behavioral characterization of Acra7-deficient mice. Learn. Mem. 1998, 5, 302-316.

17. Young, J.W.; Crawford, N.; Kelly, J.S.; Kerr, L.E.; Marston, H.M.; Spratt, C.; Finlayson, K.; Sharkey, J. Impaired attention is central to the cognitive deficits observed in alpha 7 deficient mice. Eur. Neuropsychopharmacol. 2007, 17, 145-155. [CrossRef]

18. Kolisnyk, B.; Al-Onaizi, M.A.; Prado, V.F.; Prado, M.A. $\alpha 7$ nicotinic ACh receptor-deficient mice exhibit sustained attention impairments that are reversed by $\beta 2$ nicotinic ACh receptor activation. Br. J. Pharmacol. 2015, 172, 4919-4931. [CrossRef]

19. Origlia, N.; Valenzano, D.R.; Moretti, M.; Gotti, C.; Domenici, L. Visual acuity is reduced in alpha7nicotinic receptorknockout mice. Investig. Ophthalmol. Vis. Sci. 2012, 53, 1211-1218. [CrossRef]

20. Lykhmus, O.; Kalashnyk, O.; Koval, L.; Voytenko, L.; Uspenska, K.; Komisarenko, S.; Deryabina, O.; Shuvalova, N.; Kordium, V.; Ustymenko, A.; et al. Mesenchymal stem cells or interleukin-6 improve episodic memory of mice lacking $\alpha 7$ nicotinic acetylcholine receptors. Neuroscience 2019, 413, 31-44. [CrossRef]

21. Uspenska, K.; Lykhmus, O.; Obolenskaya, M.; Pons, S.; Maskos, U.; Komisarenko, S.; Skok, M. Mitochondrial nicotinic acetylcholine receptors support liver cells viability after partial hepatectomy. Front. Pharmacol. 2018, 9, 626. [CrossRef]

22. Lykhmus, O.; Uspenska, K.; Koval, L.; Lytovchenko, D.; Voytenko, L.; Horid'ko, T.; Kosiakova, H.; Gula, N.; Komisarenko, S.; Skok, M. N-stearoylethanolamine protects the brain and improves memory of mice treated with lipopolysaccharide or immunized with the extracellular domain of $\alpha 7$ nicotinic acetylcholine receptor. Int. Immunopharmacol. 2017, 52, 290-296. [CrossRef] [PubMed]

23. Picciotto, M.R.; Caldarone, B.J.; Brunzell, D.H.; Zachariou, V.; Stevens, T.R.; King, S.L. Neuronal nicotinic acetylcholine receptor subunit knockout mice: Physiological and behavioral phenotypes and possible clinical implications. Pharmacol. Ther. 2001, 92, 89-108. [CrossRef]

24. Skok, M.V.; Voitenko, L.P.; Voitenko, S.V.; Lykhmus, E.Y.; Kalashnik, E.N.; Litvin, T.; Tzartos, S.; Skok, V.I. Alpha subunit composition of nicotinic acetylcholine receptors in the rat autonomic ganglia neurons as determined with subunit-specific anti-alpha(181-192) peptide antibodies. Neuroscience 1999, 93, 1427-1436. [CrossRef]

25. Koval, O.M.; Voitenko, L.P.; Skok, M.V.; Lykhmus, E.Y.; Tsetlin, V.I.; Zhmak, M.N.; Skok, V.I. The $\beta$-subunit composition of nicotinic acetylcholine receptors in the neurons of the guinea pig inferior mesenteric ganglion. Neurosci. Lett. 2004, 365, 143-146. [CrossRef] 
26. Lykhmus, O.; Koval, L.; Pavlovych, S.; Zouridakis, M.; Zisimopoulou, P.; Tzartos, S.; Tsetlin, V.; Volpina, O.; Cloëz-Tayarani, I.; Komisarenko, S.; et al. Functional effects of antibodies against non-neuronal nicotinic acetylcholine receptors. Immunol. Lett. 2010, 128, 68-73. [CrossRef]

27. Koval, L.; Lykhmus, O.; Zhmak, M.; Khruschov, A.; Tsetlin, V.; Magrini, E.; Viola, A.; Chernyavsky, A.; Qian, J.; Grando, S.; et al. Differential involvement of $\alpha 4 \beta 2, \alpha 7$ and $\alpha 9 \alpha 10$ nicotinic acetylcholine receptors in B lymphocyte activation in vitro. Int. J. Biochem. Cell. Biol. 2011, 43, 516-524. [CrossRef]

28. Gergalova, G.; Lykhmus, O.; Komisarenko, S.; Skok, M. $\alpha 7$ Nicotinic acetylcholine receptors control cytochrome c release from isolated mitochondria through kinase-mediated pathways. Int. J. Biochem. Cell Biol. 2014, 49, 26-31. [CrossRef] [PubMed]

29. Harlow, E.; Lane, D. Antibodies. A Laboratory Manual; Cold Spring Harbor Laboratory: New York, NY, USA, 1988; pp. 341-342.

30. Hula, N.M.; Chumak, A.A.; Horid'ko, T.M.; Kindruk, N.L.; Berdyshev, A.H. Immunosuppressive characteristics of N-stearoylethanolamine a stable compound with cannabimimetic activity. Ukr. Biokhim. Zh. 2008, 80, 57-67. (In Ukrainian)

31. Uspenska, K.; Lykhmus, O.; Gergalova, G.; Chernyshov, V.; Arias, H.R.; Komisarenko, S.; Skok, M. Nicotine facilitates nicotinic acetylcholine receptor targeting to mitochondria but makes them less susceptible to selective ligands. Neurosci. Lett. 2017, 656, 43-50. [CrossRef]

32. Antunes, M.; Biala, G. The novel object recognition memory: Neurobiology, test procedure, and its modifications. Cogn. Process. 2012, 13, 93-110. [CrossRef] [PubMed]

33. Save, E.; Poucet, B.; Foreman, N.; Buhot, M.-C. Object exploration and reactions to spatial and nonspatial changes in hooded rats following damage to parietal cortex or hippocampal formation. Behav. Neurosci. 1992, 106, 447-456. [CrossRef] [PubMed]

34. Thinus-Blanc, C. Animal Spatial Cognition: Behavioural and Brain Approach; World Scientific Publishing Company: Singapore, 1996.

35. Fann, M.J.; Patterson, P.H. Neuropoietic cytokines and activin A differentially regulate the phenotype of cultured sympathetic neurons. Proc. Natl. Acad. Sci. USA 1994, 91, 43-47. [CrossRef]

36. Lykhmus, O.; Koval, L.; Voytenko, L.; Uspenska, K.; Komisarenko, S.; Deryabina, O.; Shuvalova, N.; Kordium, V.; Ustymenko, A.; Kyryk, V.; et al. Intravenously injected mesenchymal stem cells penetrate the brain and treat inflammation-induced brain damage and memory impairment in mice. Front. Pharmacol. 2019, 10, 355. [CrossRef] [PubMed]

37. Lykhmus, O.; Kalashnyk, O.; Uspenska, K.; Skok, M. Positive allosteric modulation of alpha7 nicotinic acetylcholine receptors transiently improves memory but aggravates inflammation in LPS-treated mice. Front. Ageing Neurosci. 2020, in press.

38. IUPHAR/BPS Guide to Immunopharmacology. Available online: http://www.guidetopharmacology.org/ (accessed on 3 January 2020).

39. Baker, E.R.; Zwart, R.; Sher, E.; Millar, N.S. Pharmacological properties of alpha 9 alpha 10 nicotinic acetylcholine receptors revealed by heterologous expression of subunit chimeras. Mol. Pharmacol. 2004, 65, 453-460. [CrossRef]

40. Chernyavsky, A.I.; Arredondo, J.; Vetter, D.E.; Grando, S.A. Central role of alpha9 acetylcholine receptor in coordinating keratinocyte adhesion and motility at the initiation of epithelialization. Exp. Cell. Res. 2007, 313, 3542-3555. [CrossRef]

41. Lykhmus, O.; Voytenko, L.; Lips, K.S.; Bergen, I.; Krasteva-Christ, G.; Vetter, D.E.; Kummer, W.; Skok, M. Nicotinic acetylcholine receptor $\alpha 9$ and $\alpha 10$ subunits are expressed in the brain of mice. Front. Cell. Neurosci. 2017, 11, 282. [CrossRef]

42. Elgoyhen, A.B.; Johnson, D.S.; Boulter, J.; Vetter, D.E.; Heinemann, S. Alpha 9: An acetylcholine receptor with novel pharmacological properties expressed in rat cochlear hair cells. Cell 1994, 79, 705-715. [CrossRef]

43. Morley, B.J.; Whiteaker, P.; Elgoyhen, A.B. Commentary: Nicotinic acetylcholine receptor $\alpha 9$ and $\alpha 10$ subunits are expressed in the brain of mice. Front. Cell. Neurosci. 2018, 12, 104. [CrossRef]

44. Roncarati, R.; Scali, C.; Comery, T.A.; Grauer, S.M.; Aschmi, S.; Bothmann, H.; Jow, B.; Kowal, D.; Gianfriddo, M.; Kelley, C.; et al. Procognitive and neuroprotective activity of a novel alpha7 nicotinic acetylcholine receptor agonist for treatment of neurodegenerative and cognitive disorders. J. Pharmacol. Exp. Ther. 2009, 329, 459-468. [CrossRef] [PubMed] 
45. Nikiforuk, A.; Kos, T.; Potasiewicz, A.; Popik, P. Positive allosteric modulation of alpha 7 nicotinicacetylcholine receptors enhances recognition memory and cognitive flexibility in rats. Eur. Neuropsychopharmacol. 2015, 25, 1300-1313. [CrossRef] [PubMed]

46. Cormier, A.; Morin, C.; Zini, R.; Tillement, J.P.; Lagrue, G. In vitro effects of nicotine on mitochondrial respiration and superoxide anion generation. Brain Res. 2001, 900, 72-79. [CrossRef]

47. Schmid, H.H.O. Cannabinoid receptor-inactive N-acylethanolamines and other fatty acid amides: Metabolism and function. Prostaglandins Leukot. Essent. Fatty Acids 2002, 66, 363-376. [CrossRef] [PubMed]

48. Devane, W.A.; Hanus, L.; Breuer, A.; Pertwee, R.G.; Stevenson, L.A.; Griffin, G.; Gibson, D.; Mandelbaum, A.; Etinger, A.; Mechoulam, R. Isolation and structure of a brain constituent that binds to the cannabinoid receptor. Science 1992, 258, 1946-1949. [CrossRef] [PubMed]

49. Movahed, P.; Jønsson, B.A.; Birnir, B.; Wingstrand, J.A.; Jørgensen, T.D.; Ermund, A.; Sterner, O.; Zygmunt, P.M.; Högestätt, E.D. Endogenous unsaturated C18 N-acylethanolamines are vanilloid receptor (TRPV1) agonists. J. Biol. Chem. 2005, 280, 38496-38504. [CrossRef]

50. O'Sullivan, S.E. Cannabinoids go nuclear: Evidence for activation of peroxisome proliferator-activated receptors. Br. J. Pharmacol. 2007, 152, 576-582. [CrossRef]

51. Maccarrone, M.; Cartoni, A.; Parolaro, D.; Margonelli, A.; Massi, P.; Bari, M.; Battista, N.; Finazzi-Agrò, A. Cannabimimetic activity, binding, and degradation of stearoylethanolamide with in the mouse central nervous system. Mol. Cell Neurosci. 2002, 21, 126-140. [CrossRef]

52. Hula, N.M.; Marhitych, V.M.; Artamonov, M.V.; Zhukov, O.D.; Horid'ko, T.M.; Klimashevs'ky̆̌, V.M. Neuroprotectiveeffectof $\mathrm{N}$-acylethanolamines in chronicmorphinedependence. I. Ratbrainphospholipidsas a targetoftheiraction. Ukr. Biokhim. Zh. 2004, 76, 123-131. (In Ukrainian)

53. Hula, N.M.; Huliı̆, M.F.; Kharchenko, N.K.; Horid'ko, T.M.; Marhitych, V.M. Neuroprotective effect of $\mathrm{N}$-acylethanolamines in chronic morphine dependence. III. Influence on the content of neurotransmitters in the rat brain. Ukr. Biokhim. Zh. 2005, 7, 47-51.

54. Horid'ko, T.M.; Kosiakova, H.V.; Berdyshev, A.G.; Meged, O.F.; Onopchenko, O.V.; Klimashevsky, V.M.; Tkachenko, O.S.; Bazylianska, V.R.; Kholin, V.O.; Peschana, K.O.; et al. Preventive effect of $\mathrm{N}$-stearoylethanolamine on memory disorders, blood and brain biochemical parameters in rats with experimental scopolamine-induced cognitive impairment. Ukr. Biochem. J. 2018, 90, 97-109. [CrossRef]

55. Melis, M.; Scheggi, S.; Carta, G.; Madeddu, C.; Lecca, S.; Luchicchi, A.; Cadeddu, F.; Frau, R.; Fattore, L.; Fadda, P.; et al. PPAR $\alpha$ regulates cholinergic-driven activity of midbrain dopamine neurons via a novel mechanism involving $\alpha 7$ nicotinic acetylcholine receptors. J. Neurosci. 2013, 33, 6203-6211. [CrossRef] [PubMed]

(C) 2020 by the authors. Licensee MDPI, Basel, Switzerland. This article is an open access article distributed under the terms and conditions of the Creative Commons Attribution (CC BY) license (http://creativecommons.org/licenses/by/4.0/). 